\title{
Az alapvető pénzügyi szolgáltatások online térbe helyezésének korlátai
}

\section{Limitations of putting of basic financial services on online space KOVÁCS SÁNDOR ZSOLT}

\begin{abstract}
KOVÁCS Sándor Zsolt: tudományos segédmunkatárs, Közgazdaság- és Regionális Tudományi Kutatóközpont, Regionális Kutatások Intézete; 7621 Pécs, Papnövelde u. 22;; kovacs.sandor@krtk.mta.hu; https://orcid.org/0000-0001-6612-6296
\end{abstract}

KULCSSZAVAK: pénzügyi szolgáltatások; online banking; digitalizáció; koronavírus

Sándor Zsolt KOVÁCS: junior research fellow, Institute for Regional Studies, Centre for Economic and Regional Studies; Papnövelde u. 22.; H-7621 Pécs, Hungary; kovacs.sandor@krtk.mta.hu; https://orcid.org/0000-0001-6612-6296

KEYWORDS: financial services; online banking; digitalisation; coronavirus

\section{Előzetes helyzetkép}

Az elemzés azt a kérdést vizsgálja, hogy a napjainkat meghatározó koronavírusjárvány újabb lökést adhat-e az online banki termékek terjedésének, illetve tudjae növelni az elektronikus szolgáltatások igénybevételét?1,2

A pénzügyi szolgáltatások területén a digitalizáció folyamata már évek, évtizedek óta zajlik, s napjaink gyorsan változó információs technológiai világa, az abban megjelenő innovációk az 1990-es évek második felétől egyre inkább lehetővé tették a pénzügyi szolgáltatóknak azt, hogy tevékenységük egyes elemeit elektronikus platformokra tereljék, megnyitva az online banki ügyintézés, vagy más néven az e-banking piacát (Bruno et al. 2014). A szolgáltatók lépésről-lépésre kínálják, vagy cserélik le a hagyományos (fizikai jelenléthez kötött) termékeiket online platformokra, ezzel is megváltoztatva az emberek napi interakcióit, üzleti tevékenységét. A lakossági fogyasztóknak az az elvárása, hogy a digitális csatornákon keresztül hozzáférjenek a banki szolgáltatásokhoz (megtakarítások, számlavezetés, hitel- és bankkártyák, kölcsönök stb.), olyan új banki technológiák kialakulásához vezettek, amelyek újrafogalmazták a teljes lakossági bankpiacot. A Business Insider Intelligence felmérése szerint a lakossági ügyfelek 39\%-a költségcsökkenést, 24\%-a az ügyfélélmény javulását látja a digitalizációban (businessinsider.com).

A digitalizáció megjelenése a pénzintézetek számára egyet jelent a fióklátogatások csökkenésével, az online ügyintézési lehetőségek palettájának bővülésé- 
vel, így szükségessé válik a fiókhálózatuk felülvizsgálat (portfolio.hu). Bár egyre több banki szolgáltatás igénybe vehető online formában, a mai napig nem terjed ki a szolgáltatók teljes körére a számlanyitás, szerződésmódosítás digitális megoldásai. A lakosság mellett ez a vidéki kkv-szektor esetében is jelentős probléma, amellett, hogy a szabad szolgáltatóválasztás helyett általában a legközelebb elérhető pénzintézet szolgáltatásait veszik igénybe. Probléma, hogy a vállalati szektor esetében a legtöbb személyes megjelenéshez kötött ügyintézés fiókhoz is kapcsolt (számlavezető fiók), vagyis annak bezárásával újabb problémák merülnek fel a kiváltásában, a vállalkozók kiszolgálásának távolodásában.

\section{Nemzetközi összehasonlítás}

Mielőtt a digitális, vagy online bankolás hazai lehetőségeit elemezzük, érdemes áttekinteni, a téma európai trendjeit. Az egyik legalapvetőbb pénzügyi termékkel, a bankszámlával való rendelkezéssel kezdve vizsgáljuk meg Horn és Kiss (2019) következtetését, miszerint Magyarország tekintetében a jövedelmi viszonyok szignifikánsan befolyásolják a bankszámla feletti rendelkezést. Az 1. ábra a bankszámlával való rendelkezés különbségeit mutatja a háztartások legszegényebb 40 százaléka és leggazdagabb 60 százaléka között a Global Findex adatbá-
1. ábra: az eltérő anyagi helyzetű egyének pénzügyi szolgáltatásokban való részvételi arány, 2017 (\%)
Proportion of participation in financial services by individuals from different financial situations, 2017 (\%)

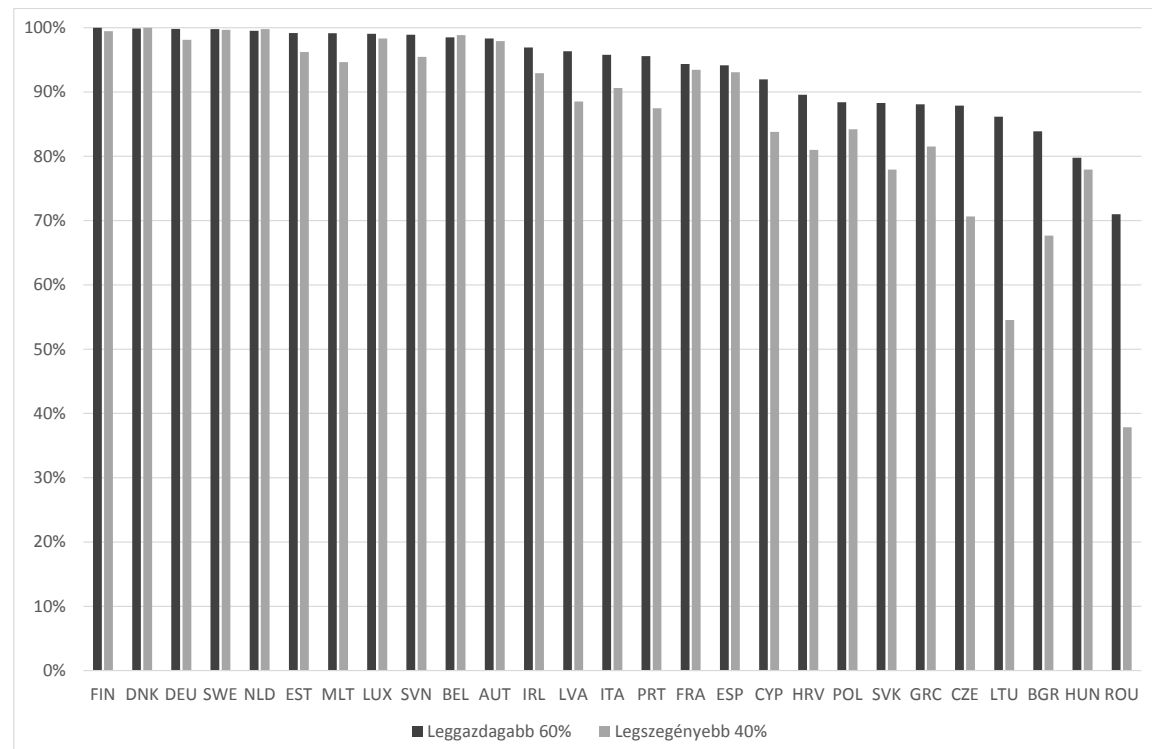

Forrás: Demirgüç-Kunt et al. 2018 adatai alapján a szerző szerkesztése 
2. ábra: A bankszámlával való rendelkezés munkaerő-piaci pozíció szerint, 2017 (\%) Account ownership by labor market position, 2017 (\%)

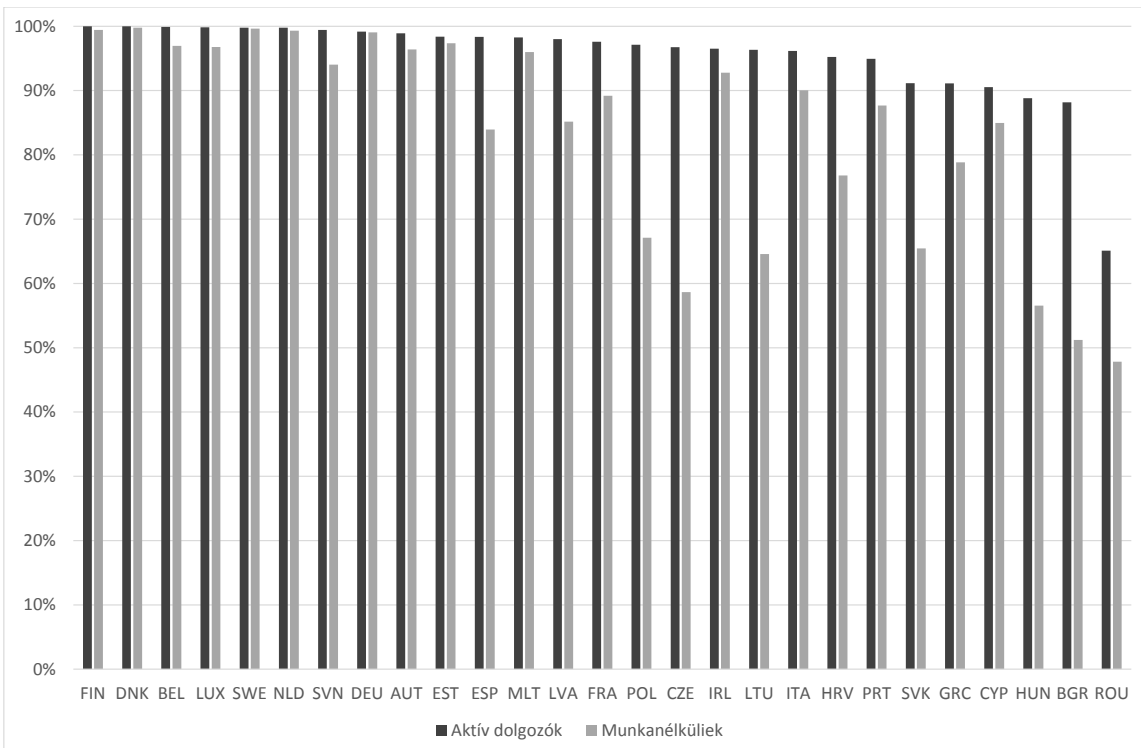

Forrás: Demirgüç-Kunt et al. 2018 adatai alapján a szerző szerkesztése

zis alapján (globalfindex.worldbank.org). Az ábra jól mutatja, hogy a két csoport közötti hazai különbség (12\%) jelentősnek számít európai kontextusban, kiemelve, hogy a kategóriák külön-külön is jelentősen elmaradnak a nyugat-európai, sőt több kelet-közép-európai adattól is.

Hasonló módon elemezve a munkapiaci aktivitást, a foglalkoztatottak és a munkanélküliek csoportjai között vizsgáltuk meg a bankszámlával való rendelkezést (2. ábra). Hazánk e tekintetben is elmarad több hasonló adottságú európai uniós országtól, sőt a két csoport közötti különbség (32,3\%) csak Bulgáriában (37\%) és Csehországban $(38,1 \%)$ nagyobb.

A területi egyenlőtlenségeket szintén a bankszámlával való rendelkezés mentén kívánjuk bemutatni, rávilágítva a vidéki területeken élők helyzetére. Az uniós átlagot tekintve a vidéki népességben mintegy 0,5 százalékkal kisebb a bankszámlabirtokosok aránya, azonban a 3. ábra szerint látható, hogy ez az érték Bulgária (6,6\%) után hazánkban a legmagasabb (6,1\%), míg például a szomszédos Horvátországban a vidéki lakosság nagyobb arányban rendelkezik önálló számlával, mint a teljes népesség.

Rátérve az online, digitális pénzügyi szolgáltatások igénybevételének elemzésére, a következőkben a digitális utalások elterjedését vizsgáljuk országos és vidéki átlagban, s a legnagyobb tanulság a nyugat-kelet lejtőben érhető tetten, illetve a város-vidék térségek elkülönülésében, ami elsősorban a kelet-európai országok jellegzetessége (4. ábra). Hazánk mind a teljes, mind a vidéki lakosságra vetítve a negyedik legrosszabb értéket mutatja, a két csoport közötti eltérésben 
3. ábra: A bankszámlával való rendelkezés eltérése a teljes és a vidéki lakosság között, 2017 (\%) Differences in account ownership between total and rural population, 2017 (\%)

\begin{tabular}{r|} 
ROU \\
BGR \\
HUN \\
CZE \\
LTU \\
SVK \\
GRC \\
HRV \\
POL \\
CYP \\
PRT \\
LVA \\
ESP \\
ITA \\
FRA \\
IRL \\
MLT \\
SVN \\
EST \\
AUT \\
BEL \\
LUX \\
DEU \\
NLD \\
SWE \\
FIN \\
DNK
\end{tabular}

$-3 \%$

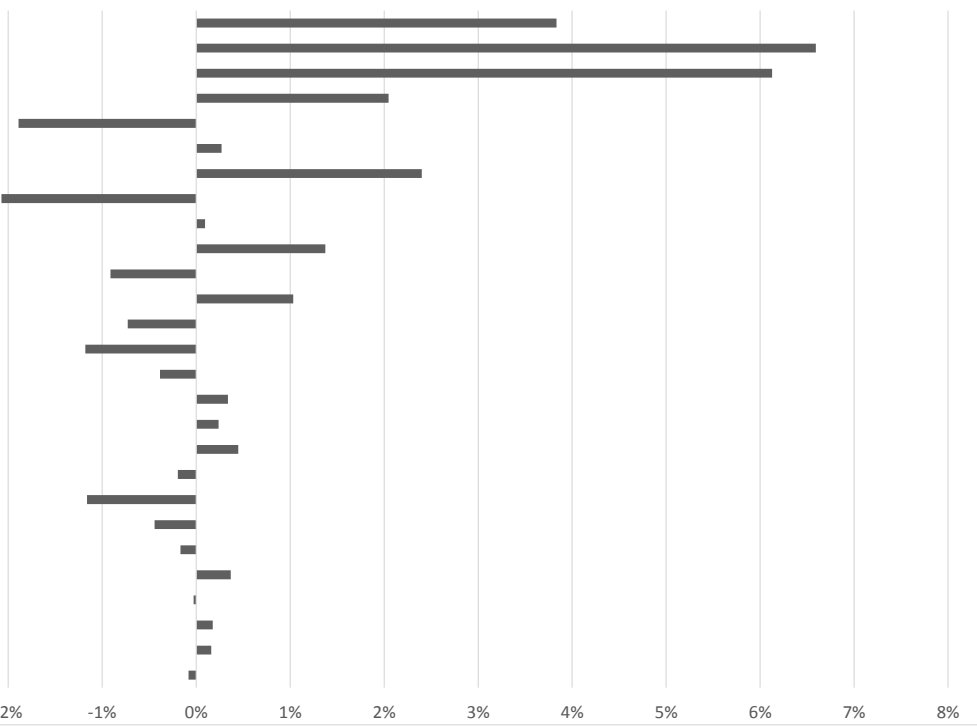

Forrás: Demirgüç-Kunt et al. 2018 adatai alapján a szerző szerkesztése

viszont szintén csak Bulgária mutat rosszabb eredményt. Összességében jelentős lemaradások vannak a digitális alkalmazások, lehetőségek használatában.

4. ábra: Digitális kifizetést indítók aránya, 2017 (\%)

Proportion of people, who made digital payment, 2017 (\%)

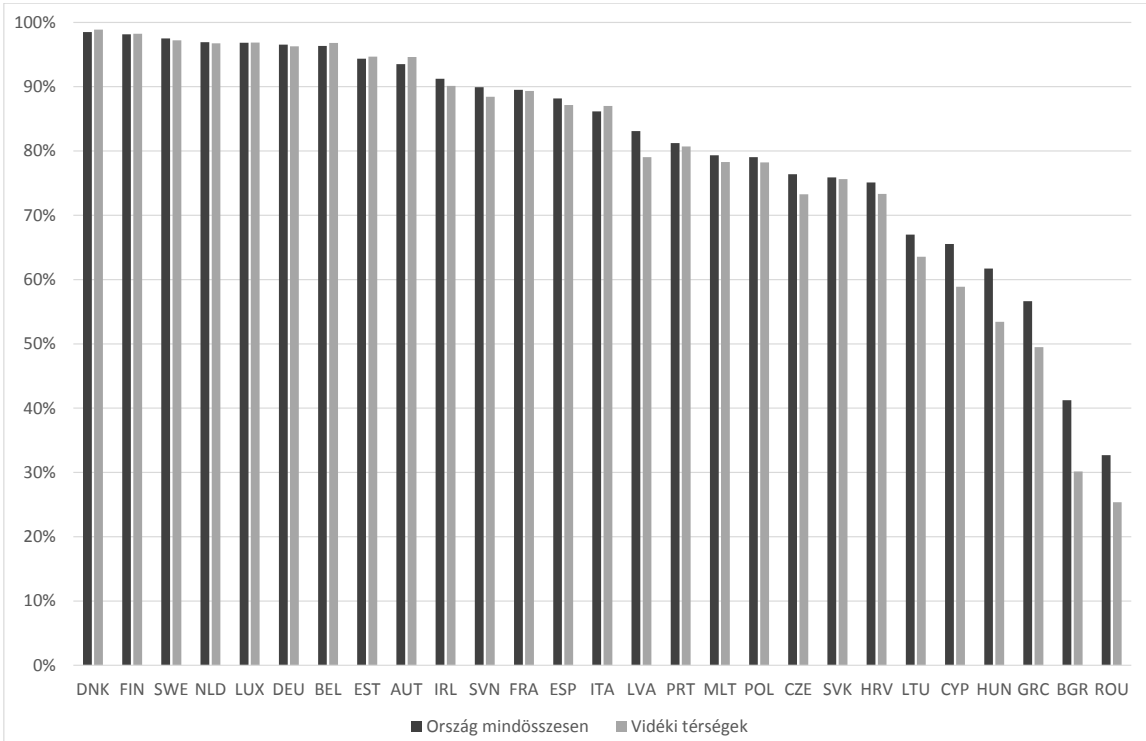

Forrás: Demirgüç-Kunt et al. 2018 adatai alapján a szerző szerkesztése 
Hosszabb idősorok vizsgálatával láthatóvá válik, hogy az online alkalmazások, így a banki ügyintézés digitális igénybevétele is dinamikusan növekszik hazánkban, azonban a megfelelő szintű bizalom még mindig nincs meg az állampolgárokban az online kereskedés és bankolás felé (Cseh 2019).

\section{Magyarországi kihívások, eredmények}

A digitális világ technológiai vívmányai az élet szinte minden területén próbálják segíteni a lakosságot, így ma már az ügyintézés, vásárlás, banki műveletek stb. részben online platformok segítségével is végezhetők (Kerényi, Müller 2019). A hazai probléma ezzel kapcsolatban az, hogy a lehetőség ugyan adott, de nem elérhető mindenhol és mindenki számára. A pénzügyi kirekesztésnek leginkább kitett területek (vidéki, periférikus falvak, tanyavilág) és társadalmi csoportok (kisnyugdíjas, leszakadó, munkanélküli rétegek) esetében az internethez való hozzáférés és a használatához szükséges tudás és eszközpark is hiányzik. Területileg vizsgálva az is látható, hogy az internetelérések és a legközelebbi elérhető fiókok statisztikái is hasonló területeken mutatják a legnagyobb problémákat (5. és 6. ábra).

Ugyancsak probléma a banki szolgáltatások digitális átállása kapcsán, hogy a kínált szolgáltatások teljes palettája még nem érhető el online formában. Ugyan 2017 óta van lehetőség arra Magyarországon, hogy otthonról, bankfióki látogatás

5. ábra: Internet-előfizetések száma 1000 lakosra vetítve, 2018

Number of Internet subscriptions per 1000 inhabitants, 2018

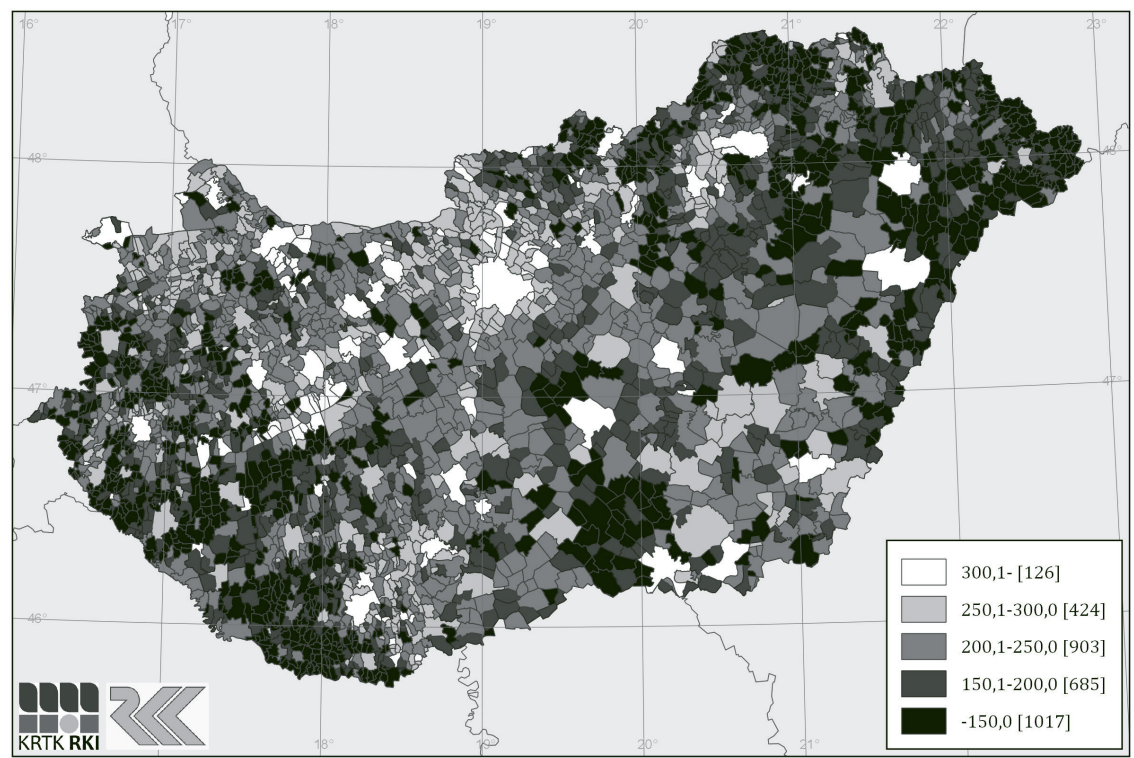

Forrás: Központi Statisztikai Hivatal adatai alapján a szerző szerkesztése 
6. ábra: A legközelebbi fiók távolsága, $2020(\mathrm{~km})$ Distance of the nearest bank branch, $2020(\mathrm{~km})$

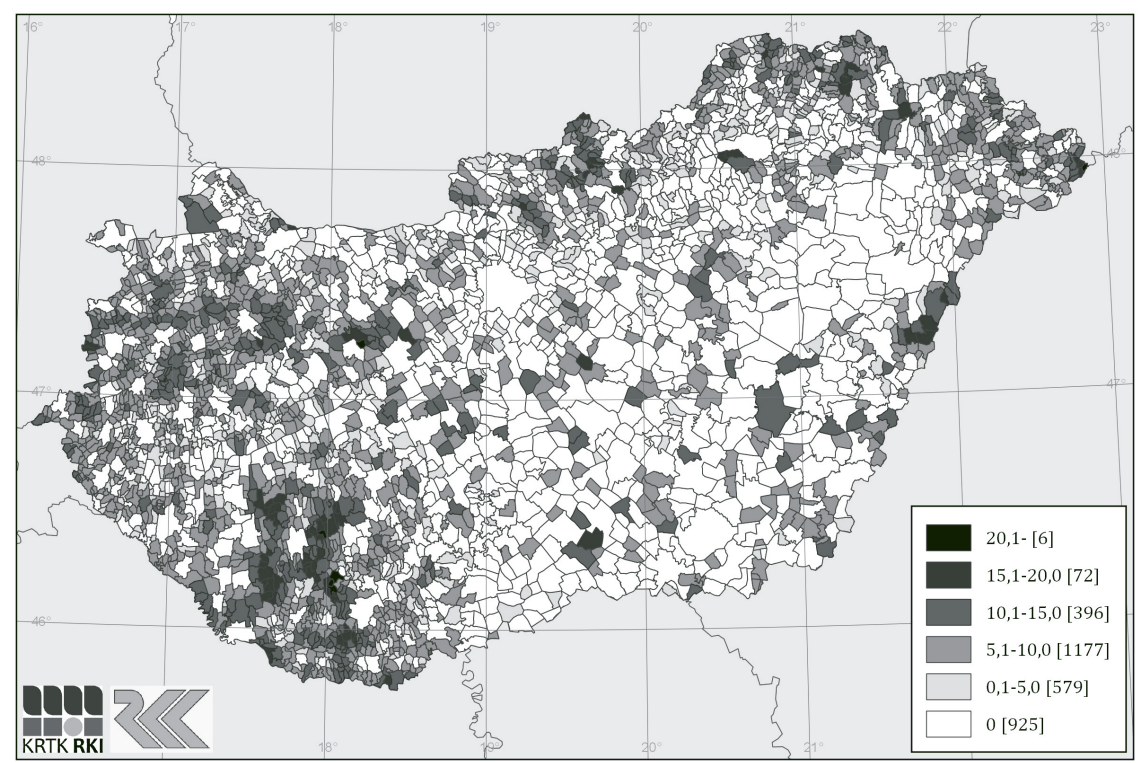

Forrás: Magyar Nemzeti Bank adatai alapján a szerző szerkesztése

nélkül nyissunk bankszámlát, mindez ma még csak részben és csak néhány bank esetében működik, nem beszélve a hitel/kölcsön felvételről, illetve megtakarítási lehetőségek (pl. állampapír vásárlás) igénybevételéről.

A felhasználók adatai alapján elmondható általánosságban, hogy a banki mobil app felhasználók száma bankonként korrelál a bank összes ügyfeleinek számával, egy-két kivételtől eltekintve, úgy, mint pl. a Takarék Mobilapp használata, mely folyamatosan romló tendenciát mutat, illetve a Raiffeisen Bank új applikációja, a myRaiffeisen, melynek használata látványosan erősödött, ami valószínűleg a korábbi app migrációjának is köszönhető.

\section{Összegzés}

Mint azt írtuk, a digitalizáció, az online platformok használata nem újkeletű az alapvető pénzügyi szolgáltatások piacán, mégis a napjainkat meghatározó koronavírus-járvány újabb lökést adott az online banki termékek, a készpénzmentes fizetési lehetőségek promóciójának és terjedésének. A fő problémát hazánkban egyre inkább nem a kínálati oldali szűkösség, hanem a keresleti oldal korlátozottsága (jövedelmi helyzet, képzettség) és a fizikai infrastruktúra (bankfiókhálózat) zsugorodásával növekvő pénzügyi kirekesztés (Kovács 2017) jelenti. Éppen ezért elengedhetetlen a szükséges kompetenciák fejlesztése, a pénzügyi ismeretek és 
kultúra fejlesztése, mert ezek nélkül jelentős előrelépés nem várható. Másrészről nem szabad megfeledkezni a banki adatok kezelésének problémáiról, az adatlopás veszélyeinek megismertetéséről sem (Burián 2014).

\section{Jegyzet}

1 Kézirat lezárva: 2020. április 13.

2 A kézirat korábbi változata, mint a KRTK Regionális Kutatások Intézete koronavírussal összefüggő műhelytanulmánya, Digitalizálhatók-e az alapvető pénzügyek a járványhelyzet hatására? címmel jelent meg, elérhetősége: http://www.docs.rkk.hu/rkkweb/Kovacs_digitalis_penzugyek.pdf

\section{Irodalom}

Bruno, P., Doshi, N., Maxwell, M. N. (2014): The Future of U.S. Retail Banking Distribution Retail Banking Insights. McKinsey \& Company, New York

Burián, G. (2005): Az Internet Banking Kockázatai. Hitelintézeti Szemle, 2., 36-56.

Cseh G. (2019): Digitális gazdaság és társadalom index - Magyarország Európai Uniós teljesítménye a digitalizált világban. Kézirat https://www.researchgate.net/publication/338140204_DIGITALIS_GAZDASAG_ES_TARSADALOM_INDEX_-MAGYARORSZAG_EUROPAI_UNIOS_TELJESITMENYE_A_DIGITALIZALT_VILAGBAN (Letöltés: 2020. április 23.)

Demirgüç-Kunt, A., Klapper, L., Singer, D., Ansar, S., Hess J. (2018): The Global Findex Database 2017: Measuring Financial Inclusion and the Fintech Revolution. World Bank: Washington, DC. https:// doi.org/10.1596/978-1-4648-1259-0

Horn D., Kiss H. J. (2019): Kinek nincs ma bankszámlája Magyarországon? Hitelintézeti Szemle, 4., 35-54. https://doi.org/10.25201/HSZ.18.4.3554

https://fintechzone.hu/icsekk-lett-a-legnepszerubb-a-koronavirus-alatt-mutatjuk-a-tobbit-is/ (Letöltés: 2020. április 10.)

https://fintechzone.hu/surgossegi-penzugyek-szamlanyitas-kolcson-mobilfizetes/ (Letöltés: 2020. április 10.)

https://globalfindex.worldbank.org/\#data_sec_focus

https://www.businessinsider.com/future-of-banking-technology (Letöltés: 2020. április 10.)

https://www.portfolio.hu/bank/20180809/a-kirugott-banki-dolgozok-es-a-bezart-bankfiokokorszaga-lettunk-294224 (Letöltés: 2020. április 10.)

Kerényi Á., Müller J. (2019): Szép új digitális világ? - A pénzügyi technológia és az információ hatalma. Hitelintézeti Szemle, 1., 5-33. https://doi.org/10.25201/HSZ.18.1.533

Kovács S. Zs. (2017): Város-vidék-kapcsolat a magyar pénzintézethálózatban. Területi Statisztika, 5., 495-511. 